納豆菌 の 開発

\title{
Development of natto starter
}

\author{
木内幹・村松芳多子
}

Kiuchi, Kan, Muramatsu, Kanako

(共立女子大学家政学部食物学科)

Department of Food Science and Nutrition, Faculty of Home Economics Kyoritsu Womens' University

\section{はじめに}

納豆は古来健康食品と見なされ, 種々の効用が言い伝 えられてきた、「納豆沿革史」によれば, アミノ酸・ビ タミンを多量に含有する, 肌の色艶を良くする, 脚気・ 皮膚病・下痢・胃ガン・心蔵病に効く, 血管を丈夫にす る，赤痢菌・チフス菌などに抗菌性があるなどの効用を 有するとされている1). 納豆を好む者はその臭いと粘り の多いものを好むが，納豆を嫌ら者もまたそれらを嫌う 傾向がある、それ故臭いの少ない納豆や粘りのない納豆 などの納豆の品質改良に関する製品開発がなされる一方 で, 納豆の食品機能性に関する知見を取り入れた製品開 発も行われてきた。

1981年須見らによってナットーキナーゼ活性が発表さ れて以来納豆が健康食品として注目されて納豆の生産高 が急増した ${ }^{2)}$ 。た, 納豆の機能性に注目して, 1995年 に天然物・生理機能素材研究会主催の公開セミナー「納 豆の機能成分と効能について」では納豆の過酸化 LDL に対する作用 (金沢武道), 抗酸化機能 (渡辺乾二), 血 圧への影響 (丸山真杉), ビタミン $\mathrm{K}$ の最近の話題 (白 幡聡), ビタミンの $\mathrm{K}_{2}$ 測定 (磯部洋祐), 骨粗鬆と納豆 摂取 (折重肇他), 血栓溶解効果 (須見洋行), 血栓溶解 活性の高い納豆菌とその増殖特性 (熊田薰), 納豆菌胞 子経口投与に上る糞便菌叢の変化 (細井智弘), 消化酵 素剂としての納豆菌（正田誠）などが報告された。そし て納豆の生理機能性に注目して納豆菌の開発がなされ, ヤマダフーズによる上述のナットーキナーゼ高生産菌の 開発 ${ }^{3)}$, 村松らによるエラスターゼ高活性納豆菌の開発 ${ }^{4)}$ が発表されている。

我々は納豆の品質改良のために高粘性高旨味納豆菌の 分離と高脂血症に効用を有すると考兄られるェラスター

本稿は第16回研究集会の発題講演を緾めたものである.
ゼ高生産菌の分離を行い, それらの納豆を用いて納豆を 製造するとともに，製品開発に付随する問題として，菌 株の保存法に関する問題, 納豆の保存上問題となるいわ ゆるチロシンの結晶析出について，また分離した納豆菌 の粘質物利用など $2-3$ の研究を行ってきたので, まと めて報告させていただく.

\section{1．エラスターゼ高生産納豆菌の開発}

エラスターゼは1949年, Balo \& Bangaによってヒト 弾性線維エラスチンの代謝酵素としてヒトすい臓中に発 見された ${ }^{5)}$ ×ラスターゼは生体内に広く分布し，すい 臓·白血球・血小板・平滑筋細胞・マクロファージ起源 の酵素が報告されている。すでにェーザイ(期からブタす い蔵エラスターゼがェラスチームといら商品名で製剤化 されている. エラスチームの効用としては高血圧患者の 血清脂質異常改善などがいわれている。

エラスターゼ高活性納豆菌の第 1 次スクリーニングと してェラスターゼ高生産納豆菌を検索するに当たり，

Bacillus subtilis を含めて当研究室の保存菌株約700株に ついてその液体培養液中に生産されたエラスターゼ活性 を測定した ${ }^{6)}$ 。その結果, 培養液の活性が市販納豆菌の 培養液のそれよりも高い菌株を78株選抜した。第 2 次ス クリーニングではさらに詳細に検討して15株を選抜し た. 第 3 次スクリーニングでは第 2 次スクリーニングで 得られた15株と市販納豆菌 4 株を用いて調べ，市販納豆 菌の活性が20〜30Uの範囲であったのに対し野生株 $\mathrm{KFP} 355$ 株の ${ }^{60} \mathrm{Co}$ 照射株である KFP419 と418株に高いエ ラスターゼ活性を見いだした4).

自動納豆製造装置 No.2（鈴与工業(侏製）を用いて， エラスターゼ高活性納豆菌 KFP419で納豆を製造した。

製造した納豆を 8 名のパネラーで官能検査を行った結 果, 親株と KFP419の納豆は特に糸引きが強く、ゴムの ような粘りを有しておらり, 市販品に比べて高い、評価が得 
表 1 納豆粘質物中のエラスターゼ活性

\begin{tabular}{lrc}
\hline 菌 株 & & $\begin{array}{c}\text { エラスターゼ活性 } \\
(\mathrm{U} / \text { 納豆 } 1 \mathrm{~g})\end{array}$ \\
\hline $\mathrm{KFP}$ & 1 & 7.25 \\
$\mathrm{KFP}$ & 2 & 4.41 \\
$\mathrm{KFP}$ & 4 & 8.30 \\
$\mathrm{KFP}$ & 418 & 14.77 \\
$\mathrm{KFP}$ & 419 & 14.82 \\
$\mathrm{KFP}$ & 355 & 12.71 \\
\hline
\end{tabular}

活性はエラスチンオルセインからオルセイン $1 \mathrm{mg} /$ 納豆 $\mathrm{g}$ を遊離 する活性を1 単位とする。

られた。外観・溶菌状態・色・臭いなどにおいては市販 納豆菌の納豆との間には大きな差が見られなかった。エ ラスターゼは納豆菌によって生産されるため, 大部分の エラスターゼ活性は粘質物中に存在すると推定されたの で, 納豆試験法によって粘質物を抽出し, エラスターゼ 活性を測定した結果, 納豆 $1 \mathrm{~g}$ 当たりのエラスターゼ活 性は，KFP419納豆で最も高い值が得られた，KFP419 と市販納豆菌 KFP 2 のとれとの比は約3.4倍であった (表 1 ). KFP419の粘質物の相刘粘度, $\boldsymbol{\gamma}$-GTP, プロ テアーゼ活性を市販納豆菌 4 株のそれらと比較してみる と, KFP419の活性は他の菌株のそれらよりも高からた。 そして全般的に粘質物の相対粘度が低くなるにつれて, $\gamma$-GTP 活性とプロテアーゼ活性も低下寸る傾向を示し た.

菅野らは原料大豆にはスクロースとスタキオースが多 く, ラフィノースとデンプン少量を検出した7). 納豆で はスクロースもスタキオースも急減し, 少量ながらマン ニ,トリオースやデンプンが主成分となっていた。

KFP419納豆ではラフィノースが減少したが，スクロー スなどの成分がまだ残存していた，菅野らとの相違は発 酵と熟成の過程によるもので, 菅野らの納豆よりも本研 究室で試作した納豆の万が，早い時期に仕上がったもの と考光るのが妥当であろら。束た，有機酸成分では最も 多いものとして酢酸, 次いで多い順にイソ吉草酸・イソ 酪酸・ヘキサン酸の順で検出された。

KFP419の大量培養を行い, その培養液からェラス ターゼを生成した。培地中に糖源としてグルコースを添 加すると，かえってェラスターゼの活性が低下してしま らので, グルコースは添加しなかった，培養液から60〜 $80 \%$ 硫安画分の沈殿物を取り, 透析, ゲルろ過クロマト グラフィー, 院イオンクロマトグラフィーを行って活性 を有する単一のピークを得た（図1）。酵素の収率は 10.0\%であった，さらに硫安溶液を用いて結晶を得た(図 2 ). SDS-PAGEにかけた結果, マーカーの泳動ハター

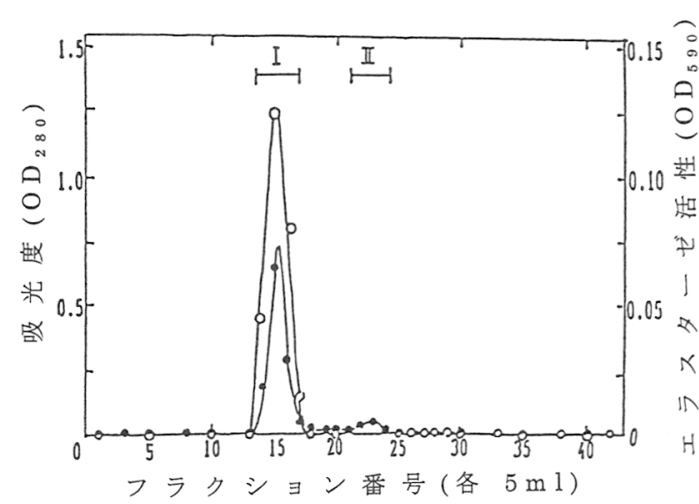

図 1 セファデックスG-75カラムクロマトグラフィーによる Bacillus subtilis (natto) KFP419エラスターゼの精製 ○：エラスターセ活性（590nmに扑怗る吸光度） : 溶出液の各フラクションのたんぱく質量 $(280 \mathrm{~nm}$ に 打吸光度)

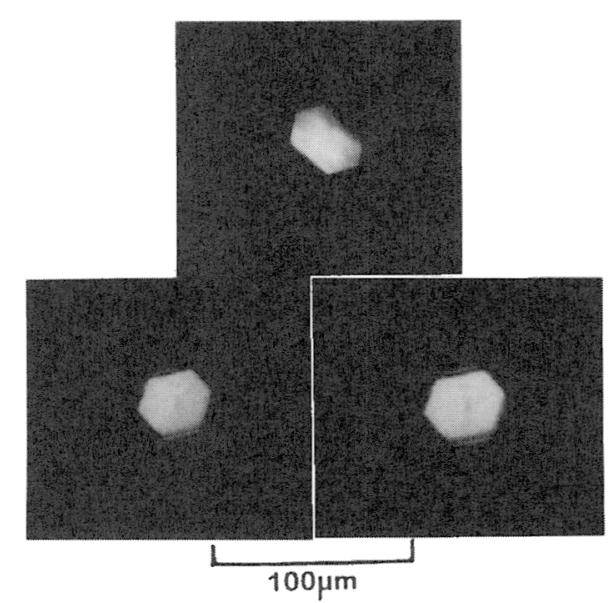

図 2 Bacillus subtilis (natto) KFP419エラスターゼの結晶

ンとェラスターゼのそれとの比較から分子量29,800と推 定された、等電点電気泳動でも単一のバンドを得た。本 酵素は凍結して未壮ば非常に安定で $4{ }^{\circ} \mathrm{C}, 210$ 日保存し た後でも $60 \%$ の残存活性が見られた。なお，エラスター ゼは $\mathrm{NaCl} と \mathrm{KCl}$ で阻害され，50mM でそれぞれ50, 25 $\% の$ 阻害が見られた。

\section{Phytone の効果}

納豆菌の開発に際し，非常に大きな問題になるのは， せっかく見つけた菌株が種々の試験を行っている期間中 あるいは保存するために継代培養を繰り返している間に 系引能 (曳系性) を消失することである。納豆菌を Nutrient Agar(NA, 牛肉ェキス $1 \%$, Polypeptone 1 


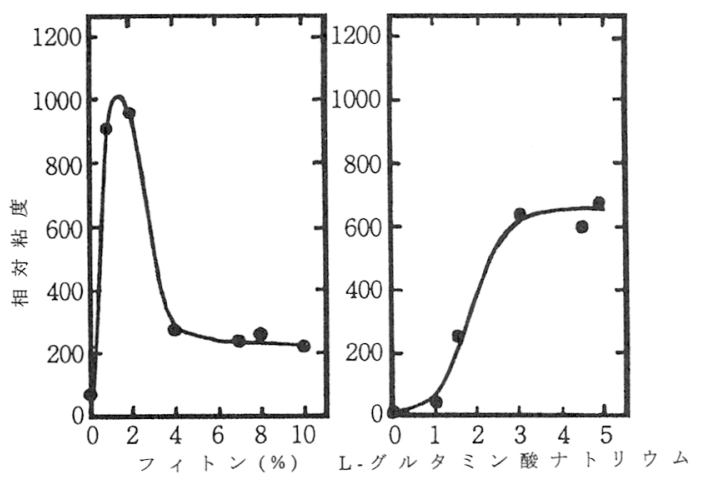

図 3 Phytone(BBL) とLーグルタミン酸ナトリウムの納豆菌粘 質物生産に及ぼす効果

データは 7 日目の培養液の相対粘度を示す。

\% $\mathrm{NaCl} 0.5 \%$ ）で継代培養していると納豆菌が粘質 物を生成しなくなることが知られていたが, NAの Polypeptone に替えて Phytone を添加して培㽰すると再び 粘質物をよく生成するよらになることを見いだした8 。 粘質物生産に及ぼす培地濃度の影響を検討するため, 基 礎培地としてスクロースとグルタミン酸を加えた合成培 地（SG 培地と称する）を使用して, SG 培地に Phytone 添加すると対照に比べて相対粘度が約 4 倍に増加 した. Phytoneの濃度は $1 \%$ が最適で，それ以上でも相 対粘度の増加は見られなかった。 また，グルタミン酸ナ トリウム濃度は3〜 5\%が最適であった (図 3$)^{9}$ ).

\section{3 。ストラバイトの生成条件}

納豆は製造後古くなると，小わゆるチロシンの結晶と いわれる白色ないし黄白色の結晶を生じ，そのため，じ ゃりじゃりした食感の悪いものになり，商品価值がなく なる、味増では「きび粒」と呼ばれているが，それは口 インン・イソロイシン・チロシンなどの結晶であること が明らかにされている。一方, ストラバイトは魚介類の 缶詰・塩蔵品・濃縮エキス・魚酱油などによく析出する ことが知られている. 田中らによって納豆の結晶はチロ シンとストラバイトであることがすでに明らかにされて (る10) が, 結晶の生成条件や納豆の品質保持との関連を 調べた報告はない。

我々はKFP419のストラバイト生成条件を明らかにす るため KFP419の液体培養で容易に結晶を析出する条件 を検討し，生成した結晶がストラバイトであることを確 認した (図 4$)^{11}$ ）結晶は蒸留水には溶解せず， $\mathrm{HCl}$ 酸 性下で容易に溶解した。アミノ酸アナライザーで分析す るとアンモニアのピーク以外には検出されず，陰イオン

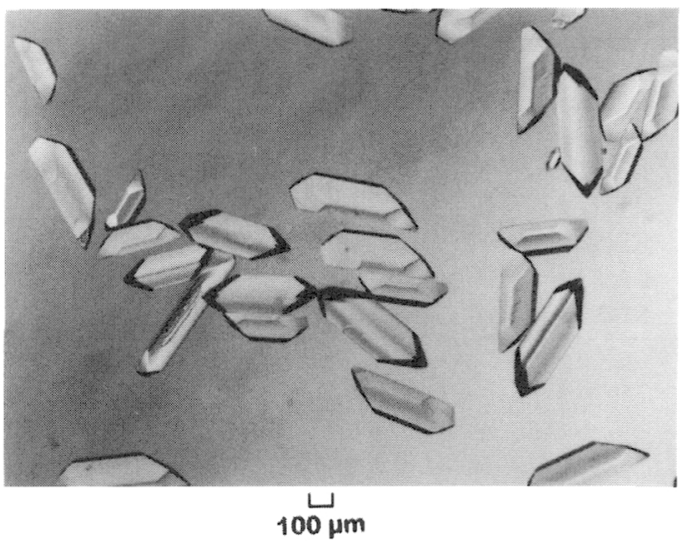

図4 Bacillus subtilis (natto) KFP419) ストラバイトの結晶

交換カラムを用いた HPLCによる無機イオンの検出て リン酸が検出された，ICP-AESによる分析で Mg と $\mathrm{PO}_{4}$ が検出され，その組成比が $\mathrm{Mg} 10.31 \%$ ，リン 12.63 \%でありストラバイト $\left(\mathrm{MgNH}_{4} \mathrm{PO}_{4} \cdot 6 \mathrm{H}_{2} \mathrm{O}\right.$ の理論值と ほぼ一致した。なお， Ca 含有量は無視しらる程度に過 ぎなかった。

納豆はたんぱく質が分解されてペプチド・アミノ酸を 経てアンモニアが生成し，その結果として $\mathrm{pH}$ が上昇す ると考光られる，培差液の液量を変えて培養条件を検討 して見た結果，ストラバイトが50～100 ml 培着で析出し たにもかかわらず， $200 \mathrm{ml}$ 培養で析出しなかったのは， ストラバイトの析出が単にアンモニアの生成によるだけ ではなく, Mgとリンの代謝にも関係していることを示 唆している。培地の初発 $\mathrm{pH}$ を変えて培責しストラバイ トの生成を見ると， pH5～9の範井でストラバイトが生 成するが，その時最終 $\mathrm{pH}$ が 8 以上になっており，アル カリ性の時よく生成することが明らかになった。ストラ ハヘイトの生成を経時的に追ってみると，培養しない培地 では 2 週間経ってもストラバイトの生成は見られなかっ た。 3 日目末での培地ではストラバイトの生成は少ない が，4 日目以降の培地では装日にはストラバイトの生成 が見られた。培地中の $\mathrm{Mg}$ とリンの量がストラバイト の析出に影響していると推定されたので，培地成分の牛 肉ェキス・ポリペプトン・Phytoneの Mgとリンを測 定した。ポリペプトンに比べPhytone 中にはかなりの 量の $\mathrm{Mg}$ が存在していることが明らかになった（図 5 ).

ストラバイトが等量のアンモニウム，マグネシウム， リン酸イオンから構成されているので，3イオンの内 2 イオン濃度を一定にしてマグネシウムあるいはリン酸イ オン濃度を变えてストラバイトの生成量を測定した結 


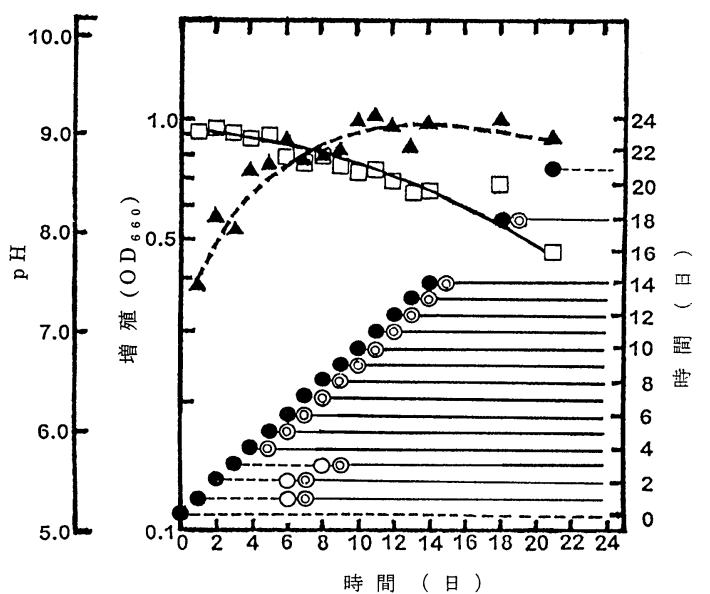

図 5 培養期間とストラバイト生成の関係

$\boldsymbol{\Delta}: \mathrm{pH}, \square$ : 増殖（吸光度 $660 \mathrm{~nm}$ ), 0 : 結晶は検出さ れず，○：少量の結晶が見られる，〕：結晶が見られる

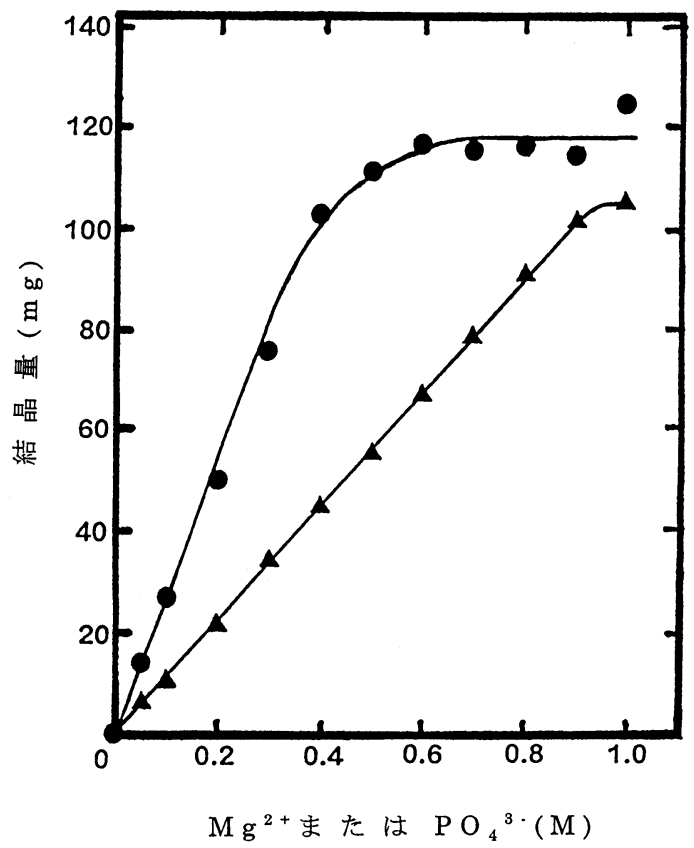

図 6 ストラバイト生成に及ぼす $\mathrm{Mg}^{2+}, \mathrm{PO}_{4}{ }^{3-}, \mathrm{NH}_{4}{ }^{+}$依存性 横軸は $\mathrm{PO}_{4}{ }^{3-}$ と $\mathrm{NH} 4+$ 濃度を1.0Mに一定にして $\mathrm{Mg}^{2+}$ 濃度を変えた時の濃度と, $\mathrm{Mg}^{2+}$ と $\mathrm{NH}_{4}+$ 濃度を $1.0 \mathrm{M}$ に 一定にして $\mathrm{PO}_{4}{ }^{3-}$ 濃度を变えたときの濃度を示す。
果，マグネシウムがリン酸イオンよりも低濃度でストラ バイトを多く生成することが明らかになった（図 6 ）。

今後大豆中の $\mathrm{Mg}$ とリンが大豆のどの部位に存在し, 無機イオンとなって，大豆表面に移動して結晶化するの かを検討する必要があると考光ている。

\section{文献}

1）フーズパイオニア：納豆沿革史，全国納豆協同組合連 合会, p . 243-280 (1975)

2) Sumi, H., Hamada, H., Tsusima, H., Mihara, H. and Muraki, H.: A novel fibrinolytic enzyme (nattokinase) in the vegetable cheese Natto, a typical and popular soybean food and in the Japanese diet, Experientia, 43, 1110-1111 (1987)

3）木内幹, 鈴木英也：高活性ナットウキナーゼ納豆開発 の現状，食品と科学，33．1-4（1991）

4）村松芳多子，金井幸子，木村倫代，三浦紀子，吉田桂 子, 木内幹：エラスターゼ高活性納豆の開発, 食科工誌, 42, 575-582 (1995)

5) Balo, J. \& Banga, I.: Elastase and elastase inhibitor, Nature, 4168, 491 (1949)

6）永井利郎, 西村和典, 鈴木英也, 番場康夫, 佐々木裕, 木内幹, 日食工誌, 41，123-128（1994）

7）菅野彰重，高松春樹，高野伸子，秋本隆司：納豆製造 工程に护汁る糖成分の動向，日食工誌，29，105（1982）

8) Sulistyo, J., Taya, N., Funane, K. and Kiuchi, K.: Nippon Shokuhin Kogyo Gakkaishi, 35, 278-283 (1988)

9）村松芳多子, 永井利郎, 佐藤志津子, 落合祐子, 石村 典子，伊藤義文，木内幹：納豆菌の粘質物生産に及ぼす Phytone の効果，食科工誌，44，812-815（1997）

10）田中米實，富安行雄，栄食誌，26，473-（1973）

11）村松芳多子, 村岡靖彦, 安井明美, 鈴木忠直, 木内幹 : 納豆菌, Bacillus subtilis（natto）KFP419によるストラバ イトの生成，食科工誌，44，285-289（1997） 